\title{
PENGARUH KOMERSIALISASI BIAYA RAWAT INAP PASIEN TERHADAP KINERJA RUMAH SAKIT
}

(Studi Kasus pada Rumah Sakit Umum Daerah Kota Tasikmalaya)

\author{
Oleh : • \\ Agus Widarsono \\ (Dosen Program Studi Akuntansi Fakultas Pendidikan Ekonomi \& Bisnis UPI BHMN Bandung) \\ Rini Rividyasari \\ (Alumni Jurusan Akuntansi Fakultas Ekonomi Universitas Siliwangi Tasikmalaya)
}

\begin{abstract}
Abstrak
Perkembangan terakhir Rumah Sakit, semakin menunjukkan bahwa rumah sakit secara de facto telah bergeser dari lembaga sosial menjadi sebuah lembaga usaha. Rumah sakit yang dahulu tidak pernah memikirkan masalah untung rugi karena semata-mata didirikan untuk kepentingan sosial dan kemanusiaan, pada saat ini telah berubah menjadi salah satu aktivitas usaha yang cenderung bersifat ke-ekonomian. Penelitian ini dilakukan dengan tujuan untuk mengetahui bagaimana komersialisasi biaya rawat inap pasien di RSUD, mengetahui bagaimana kinerja RSUD, dan mengetahui bagaimana pengaruh komersialisasi biaya rawat inap pasien terhadap kinerja rumah sakit, menggunakan metode deskriptif analisis dengan pendekatan studi kasus. Berdasarkan hasil analisis data menggunakan uji statistik, untuk mengetahui ada tidaknya hubungan pada tingkat keyakinan $95 \%$ menunjukkan bahwa terdapat hubungan yang positif antara variabel komersialisasi biaya rawat inap pasien dengan kinerja rumah sakit. Hal tersebut didukung dengan data hasil pengujian koefisien korelasi yang menyatakan derajat hubungan antara variabel tersebut adalah positif. $r$ square menyatakan, kinerja rumah sakit dipengaruhi oleh komersialisasi biaya rawat inap pasien, yang menunjukkan bahwa hubungan kedua variabel adalah signifikan, sedangkan sisanya dipengaruhi faktor-faktor lain. Pengujian hipotesis yang dilakukan dengan membandingkan thitung dengan $\mathbf{t}_{\text {tabel, }}$ menunjukkan bahwa $\mathbf{t}_{\text {hitumg }}$ lebih besar daripada tabel dengan demikian Ho ditolak, maka Ha diterima artinya terdapat pengaruh yang signifikan antara komersialisasi biaya rawat inap pasien terhadap kinerja rumah sakit.
\end{abstract}

Kata Kunci : Komersialisasi Biaya Rawat Inap Pasien dan Kinerja Rumah Sakit

\section{Latar Belakang Penelitian}

Rumah sakit di Indonesia sekarang ini tidak lagi sekedar sebagai tempat perawatan yang terbatas, tetapi telah menjadi institusi sosial. Menurut Pasal 6 Permenkes RI Nomor 159b Tahun 1988 tentang Rumah Sakit, penyelenggaraan kegiatan rumah sakit harus mendapat ijin dari Menteri Kesehatan. Selanjutnya menurut 
Pasal 8 ayat (2) Permenkes RI Nomor 532 Tahun 1982, untuk memperoleh ijin dari Menteri Kesehatan rumah sakit dimiliki dan diselenggarakan oleh badan hukum. Hal tersebut merupakan pelaksanaan Pasal 58 UU Nomor 23 Tahun 1992 tentang Kesehatan, bahwa rumah sakit sebagai suatu lembaga yang diselenggarakan dan dimiliki oleh masyarakat maupun swasta harus berbentuk badan hukum, dengan maksud agar mudah di dalam melakukan pengawasannya. Ternyata ketentuan Pasal 58 UU Nomor 23 Tahun 1992 tersebut memberikan pengecualian, yaitu rumah sakit yang diselenggarakan dan dimiliki oleh pemerintah tidak perlu berbentuk badan hukum, karena pemerintah sendiri merupakan badan hukum publik.

Berdasarkan Peraturan pemerintah Nomor 23 tahun 2005 tentang Badan Layanan Umum Pasal 8 menyatakan standar pelayanan minimum harus mempertimbangkan kualitas layanan, pemerataan dan kesetaraan layanan, biaya serta kemudahan untuk mendapatkan layanan.

Rumah sakit pemerintah maupun rumah sakit swasta di dalam menyelenggarakan kegiatannya, menurut Pasal 57 ayat (2) UU Nomor 23 Tahun 1992 tentang Kesehatan harus tetap memperhatikan fungsi sosial. Adapun yang dimaksud dengan fungsi sosial menurut penjelasan Pasal 57 ayat (2) UU Nomor 23 Tahun 1992 tentang Kesehatan adalah penyelenggaraan kegiatan setiap sarana kesehatan harus memperhatikan kebutuhan pelayanan kesehatan golongan masyarakat yang kurang mampu dan tidak semata-mata mencari keuntungan secara komersial, tetapi lebih dititikberatkan kepada kemanusiaan.

Menurut Kartono Mohammad (2005), penyelenggaraan rumah sakit pada zaman modern tidak sesederhana dulu lagi. Kebutuhan untuk mengelola rumah sakit dengan prinsip bisnis tidak dapat dielakkan. Penyelenggaraan rumah sakit masa sekarang membutuhkan modal yang cukup besar terutama dengan makin banyaknya teknologi baru yang harus disediakan, tenaga yang cukup banyak sehingga memerlukan pengorganisasian yang lebih profesional, dan tersedianya tenaga-tenaga teknis yang mahir untuk menangani alat-alat yang makin canggih. Ditambah lagi dengan adanya perubahan tuntutan dari masyarakat pemakai jasa rumah sakit berupa kenyamanan dan kemudahan dalam pelayanan kesehatan yang semua itu memerlukan biaya yang sangat besar.

Perkembangan terakhir ini semakin menunjukkan bahwa rumah sakit secara de facto telah bergeser dari lembaga sosial menjadi sebuah lembaga usaha. Rumah sakit yang dahulu tidak pernah memikirkan masalah untung rugi karena semata-mata didirikan untuk kepentingan sosial dan kemanusiaan, pada saat ini telah berubah menjadi salah satu kegiatan ekonomi. Keadaan tersebut jelas mempunyai dampak ganda, yaitu disatu pihak positif bagi kehidupan manusia, namun di pihak lain timbul berbagai dilema etika biomedis dan komersialisasi jasa kesehatan. (Wijaya, $2000: 1$ )

RSUD Kota Tasikmalaya yang merupakan rumah sakit milik pemerintah yang juga mengemban tugas sosial ini, dalam rangka memberikan pelayanan yang optimal kepada masyarakat juga terdapat komersialisasi didalammya. Hal tersebut dapat dilihat salah satunya dari adanya tingkatan kelas ruang rawat inap pasien dengan sarana dan fasilitas yang berbeda pada setiap kelas.

Pada kelas VIP terdapat fasilitas televisi, kulkas, air condition, ruang tamu, satu buah tempat tidur pasien dan satu buah tempat tidur untuk penunggu pasien, serta kamar Jurnal Akuntansi Riset, Prodi Akuntansi UPI, Vol. 1, No. 2 
mandi di dalam ruangan. Pada kelas utama terdapat televisi, kulkas, air condition, ruang tamu, satu buah tempat tidur pasien, kamar mandi di dalam ruangan. Pada kelas I terdapat fasilitas dua buah tempat tidur pasien dan satu buah kamar mandi di dalam ruangan. Pada kelas II terdapat fasilitas dua buah tempat tidur pasien dan kamar mandi di luar ruangan. Sedangkan pada kelas III terdapat lebih dari dua buah tempat tidur pasien serta kamar mandi di luar ruangan.

Selain adanya fasilitas yang berbeda, banyaknya pasien rawat inap di RSUD Tasikmalaya juga berbeda pada tiap ruangan. Dari laporan tahunan RSUD Tasikmalaya tahun 2002, pada kelas VIP terdapat 616 pasien/tahun atau 75,51\%, pada kelas utama terdapat 511 pasien/tahun atau $89,04 \%$, pada kelas I terdapat 1048 pasien/tahun atau $80,54 \%$, pada kelas II terdapat 754 pasien/tahun atau $31,86 \%$, sedangkan pada kelas III terdapat 1234 pasien/tahun atau $45,20 \%$.

Komersialisasi biaya rawat inap pasien tersebut tidak dapat dihindari karena adanya berbagai faktor. Salah satunya antara lain adanya tuntutan dari masyarakat pemakai jasa rumah sakit berupa kenyamanan dan kemudahan dalam pelayanan kesehatan.

Untuk dapat memberikan pelayanan yang optimal tersebut, maka rumah sakit harus memiliki kinerja yang sangat baik. Agar kinerja rumah sakit dapat berjalan dengan baik, maka harus ada suatu pengukuran yang mengindikasikan peningkatan dan keberhasilan kinerja rumah sakit.

\section{Rumusan Masalah}

Berdasarkan hal yang dikemukakan di atas, dapat ditemukan rumusan penelitian sebagai berikut :

1.Bagaimana komersialisasi biaya rawat inap pasien di RSUD Kota Tasikmalaya

2.Bagaimana kinerja RSUD Kota Tasikmalaya dengan menggunakan pendekatan Economic Value Added

3.Bagaimana pengaruh komersialisasi biaya rawat inap pasien terhadap kinerja rumah sakit

\section{Kerangka Pemikiran}

Seiring dengan perkembangan ekonomi dan peningkatan pendapatan masyarakat, maka kesadaran akan pemeliharaan pun meningkat. Untuk memperoleh tingkat kesehatan yang maksimal, maka diperlukan sarana dan prasarana penunjang yang memadai. Hal ini tentu saja pelayanan yang dibutuhkan oleh masyarakat. Agar dapat memberikan pelayanan yang optimal, dalam pengelolaan rumah sakit yang pada umumnya mengemban misi sosial ini, dibutuhkan pula manajemen yang profesional.

Sekarang ini terjadi pergeseran bahkan perubahan orientasi penyelenggaraan rumah sakit dari pelayanan kesehatan yang berfungsi sosial menjadi komersial. Rumah sakit tidak lagi berupa tempat karya amal. Profesionalisme, manajemen, efisiensi adalah paham-paham yang sudah tidak asing lagi dalam kalangan medis, termasuk juga rumah sakit. Oleh sebab itu rumah sakit semakin dibayangi komersialisasi atau bisnis. (Ahdiana, 2002:12) 
Sebenarnya pengertian komersialisasi dan bisnis tidak menunjukkan sesuatu yang negatif, apalagi sesuatu yang terlarang. Komersialisasi dimaksudkan menjadikan sesuatu sebagai barang dagangan (Tim Penyusun Kamus Besar Bahasa Indonesia, 1995 : 515). Selanjutnya dalam Kamus Besar Bahasa Inggris, komersialisasi atau to commercialize artinya mengelola suatu kegiatan bisnis untuk tujuan mencari keuntungan (Echols \& Shadily, $1990: 130$ ).

Menurut Peraturan Pemerintah No 23 Tahun 2005 Tentang Badan Layanan Umum Pasal 2 menyebutkan bahwa pola pengelolaan keuangan badan layanan umum memberikan fleksibilitas berupa keleluasaan untuk menerapkan praktek-praktek bisnis yang sehat untuk meningkatkan pelayanan kepada masyarakat dalam rangka memajukan kesejahteraan umum dan mencerdaskan kehidupan bangsa. Dan menurut Pasal 1 ayat 12 menjelaskan bahwa praktek bisnis yang sehat adalah penyelenggaraan fungsi organisasi berdasarkan kaidah-kaidah manajemen yang baik dalam rangka pemberian layanan yang bermutu dan berkesinambungan.

Seperti yang telah dikemukakan diatas, karena adanya banyak faktor maka komersialisasi rumah sakit tidak dapat dihindari, tetapi tidak berarti tidak perlu dilandasi oleh etika. Menurut Thiroux, etika bisnis harus didasari oleh paling sedikit dua prinsip, yaitu truth telling (berbicara benar) dan honesty (kejujuran) (Thiroux, 1980 : 45).

Dalam bukunya "Akuntansi Biaya" Mulyadi mengemukakan pengertian biaya dalam arti sempit, "Biaya dapat diartikan sebagai pengorbanan sumber ekonomi untuk memperoleh aktiva" (Mulyadi, 1999 : 8). Sedangkan biaya dalam arti luas dijelaskan bahwa "Biaya adalah pengorbanan yang diukur dalam satuan uang, yang telah terjadi atau yang mungkin akan terjadi untuk tujuan tertentu" (Mulyadi, 1999 : 8).

Jasa rawat inap merupakan bagian terbesar dalam memperoleh pendapatan rumah sakit, maka diperlukan berbagai pelayanan penunjang yang mengurusi bagian kerumahtanggaan dan administrasi. Bagian ini secara menyeluruh mendukung rumah sakit dalam menjalankan fungsinya secara instrumental, yaitu kegiatan pelayanan rumah sakit, termasuk didalamnya pelayanan medis dan pelayanan penunjang non medis.

Pada umumnya rumah sakit dalam melaksanakan fungsi sosial rumah sakitnya adalah sesuai dengan tekstual peraturan yang telah ditetapkan oleh pemerintah, yaitu telah menyediakan fasilitas tempat tidur bagi pasien tidak mampu sejumlah minimal $25 \%$ dari seluruh fasilitas tempat tidur yang ada. Rumah sakit semata-mata menerjemahkan fungsi sosial ke dalam bentuk tarif kamar bukan biaya pelayanan yang sebenarnya. Tarif dan biaya tersebut disesuaikan dengan kelas dimana pasien dirawat. Adanya berbagai macam biaya kesehatan itulah yang menyebabkan biaya kesehatan menjadi mahal, dan tampak wajah komersilnya. (Ahdiana, $2002: 28$ )

Menurut keputusan Menteri Kesehatan Republik Indonesia Nomor 282/Men. Kes./III/1993 tentang pola tarif rumah sakit dikemukakan pengertian tarif rumah sakit bahwa tarif adalah harga komponen atau kegiatan yang dibebankan kepada masyarakat sebagai imbalan atas pelayanan yang diterima dari rumah sakit.

Selanjutnya pada dasarnya tarif pelayanan rumah sakit berdasarkan biaya yang dikeluarkan untuk pemberian jasa, tetapi tetap memperhatikan ekonomi masyarakat, rumah sakit pesaing dan kebijakan intern rumah sakit atas dasar jenis pelayanan, tingkat kecanggihan pelayanan dan kelas perawatan.

Adapun faktor-faktor yang mempengaruhi tarif, diantaranya :

Jurnal Akuntansi Riset, Prodi Akuntansi UPI, Vol. 1, No. 2 


\section{Biaya Satuan}

Informasi biaya satuan (unit cost) adalah informasi yang menggambarkan besarnya biaya pelayanan pada pasien (besar pengobatan faktor produksi untuk menghasilkan pelayanan). Informasi ini merupakan informasi pertama yang digunakan untuk menetapkan tarif, selain itu juga terdapat manfaat untuk menilai skala ekonomis produk yang dihasilkan.

2.Jenis Pelayanan, Tingkat Pemanfaatan dan Subsidi Silang yang Diharapkan Jenis pelayanan dan tingkat pemanfaatan merupakan salah satu faktor penting yang perlu diperhatikan dalam penyesuaian tarif, dimana rumah sakit yang terdiri dari berbagai unit produksi memiliki potensi yang berbeda-beda dengan rumah sakit lainnya. Pertimbangan subsidi silang antar kelas perawatan yang perlu dipertimbangkan adalah ruang perawatan kelas III yang tarifnya ditetapkan atau disesuaikan oleh pemerintah dengan tujuan fungsi sosial melayani kelompok masyarakat yang kurang mampu, merupakan unit-unit yang membutuhkan subsidi unit lain yang potensial dan diharapkan memperoleh pendapatan relatif besar melalui penyesuaian tarif, sehingga dapat menutupi subsidi kelas III (subsidi silang).

Menurut Peraturan Pemerintah Republik Indonesia Nomor 66 tahun 2001 Pasal 8 tentang Retribusi Daerah dikemukakan bahwa :

"Tarif rawat inap kelas tinggi bagi retribusi pelayanan rumah sakit umum daerah dapat ditetapkan lebih besar daripada biaya pelayanannya, sehingga memungkinkan adanya subsidi silang bagi tarif rawat inap kelas yang lebih rendah".

Menurut Trisnantoro (2000), mekanisme subsidi silang ini dalam era manajemen modern, sama sekali tidak masuk akal. Dalam persaingan ketat, tidak mungkin diharapkan bahwa semua orang kaya yang sakit pasti akan mau mensubsidi orang miskin yang sakit. Orang kaya yang sakit pun akan mencari pengobatan yang terbaik dan paling efisien. Berbagai pengamatan menunjukkan bahwa konsep subsidi silang ternyata tidak ada, ataupun jika ada konsep subsidi silang ini akan menggerogoti aset dan kemampuan rumah sakit yang bersangkutan.

Menurut Laksono pula, pendekatan yang lebih masuk akal dan tepat dalam pembiayaan kesehatan ini adalah berdasarkan subsidi atau donor. Selain dengan mekanisme subsidi, Laksono menawarkan alternatif lain untuk pembiayaan pasien tidak mampu, yaitu dengan mencari dana kemanusiaan.

3. Tingkat Kemampuan Masyarakat

Salah satu persyaratan dalam penetapan tarif rumah sakit adalah mempertimbangkan kemampuan masyarakat membayar diukur dengan cara melihat ATP (Ability To Poy) dan WTP (Willingness To Pay) masyarakat.

4.Elastisitas

Angka elastisitas sangat bermanfaat untuk memproduksi kemungkinan penurunan jumlah output rumah sakit bila dilakukan penyesuaian tarif.

5.Tarif pelayanan pesaing yang setara

Meskipun telah menghitung biaya satuan dan tingkat kemampuan masyarakat, rumah sakit perlu memperhitungkan tarif pelayanan pesaing yang setara, misalnya tarif poliklinik, praktek bidan, tarif dokter praktek dan tarif rawat inap. Rumah sakit lain merupakan faktor penting untuk pembanding adalah kualitas pelayanan yang 
diberikan, apakah rumah sakit bersaing dengan pesaing yang memiliki tarif serupa, namun pelayanan yang diberikan berbeda.

Namun pada saat ini rumah sakit semakin berkembang sesuai dengan tuntutan perkembangan zaman. Hal ini berlaku pada rumah sakit "sosial" agar tidak tersaingi oleh rumah sakit "pemodal", dimana rumah sakit yang dimiliki pemodal dikelola secara profesional.

Untuk meningkatkan kualitas pelayanan kepada masyarakat, rumah sakit harus memiliki kinerja yang baik. Kinerja adalah pernyataan yang menyajikan ukuran hasil yang sebenarnya dari beberapa kegiatan pribadi atau kesatuan pada periode waktu yang sama. (Siegel, Shim dalam Kurdi, 1999 : 340)

Untuk mengukur kinerja rumah sakit tersebut dapat diukur salah satunya dengan menggunakan pendekatan EVA (Economic Value Added). EVA adalah suatu estimasi laba ekonomis yang benar atau suatu bisnis selama tahun tertentu. (Warsono, 2003 : 48)

Young dan O'Byrne (2001 : 39) mengungkapkan perhitungan EVA dengan cara yang lebih sederhana dan mudah diterapkan sebagai berikut :

EVA $=$ NOPAT - (WACC $\times$ Average Invested Capital $)$

NOPAT merupakan laba operasi perusahaan setelah pajak, dan meningkatkan laba yang diperoleh perusahaan dari operasi berjalan.

WACC atau biaya bunga rata-rata tertimbang perusahaan adalah merupakan gabungan dari biaya-biaya individual yang ditimbang dengan presentasi pembiayaan dari setiap sumber dana. Dan Average Invested Capital merupakan modal investasi ratarata.

Dari penjelasan tersebut, jelas terlihat bahwa EVA sangat bermanfaat untuk digunakan sebagai penilai kinerja perusahaan dimana fokus penilaian kinerja adalah pada penciptaan nilai (value creation). Dengan adanya pembedaan tarif ini akan berpengaruh pada tingkat kinerja rumah sakit karena akan lebih memberikan motivasi kepada para tenaga medis maupun non medis untuk dapat menyediakan dan memberikan pelayanan kepada masyarakat secara optimal.

Adapun hipotesis yang penulis ajukan adalah sebagai berikut:

${ }^{66}$ Terdapat pengaruh yang signifikan dari Komersialisasi Biaya Rawat Inap Pasien terhadap Kinerja Rumah Sakit".

\section{Metode Penelitian}

Metode yang digunakan dalam penelitian ini adalah metode deskriptif analitis dengan pendekatan studi kasus. Sedangkan rancangan analisis data yang digunakan menggunakan analisis regresi sederhana.

Dalam penelitian ini penulis melakukan analisis pada besarnya pengaruh yang ditimbulkan variabel independen terhadap variabel dependen atau pengaruh komersialisasi biaya rawat inap pasien terhadap kinerja rumah sakit. Untuk lebih jelasnya mengenai variabel penelitian yang penulis gunakan dalam penelitian ini dapat dilihat dalam Tabel berikut: 
Tabel Operasionalisasi Variabel

\begin{tabular}{|c|c|c|c|c|}
\hline Variabel & Definisi & Indikator & Satuan & Skala \\
\hline $\begin{array}{l}\text { Variabel }(\mathrm{X}) \\
\text { Komersialisasi } \\
\text { Biaya Rawat } \\
\text { Inap Pasien }\end{array}$ & $\begin{array}{l}\text { Merupakan proses } \\
\text { mengkomersialkan hasil } \\
\text { riset baik dilakukan } \\
\text { sendiri maupun orang } \\
\text { lain. } \\
\text { (http://www.drn.go.id/do } \\
\text { wnload/p.doc. 20:45, 20 } \\
\text { Mei 2007) }\end{array}$ & $\begin{array}{l}\text { - Biaya Jasa Pelayanan } \\
\text { - Biaya Jasa Sarana }\end{array}$ & $\begin{array}{l}\text { Rupiah } \\
\text { (Rp) }\end{array}$ & Rasio \\
\hline $\begin{array}{l}\text { Variabel (Y) } \\
\text { Kinerja Rumah } \\
\text { Sakit }\end{array}$ & $\begin{array}{l}\text { Pernyataan yang } \\
\text { menyajikan ukuran hasil } \\
\text { yang sebenarnya dari } \\
\text { beberapa kegiatan pribadi } \\
\text { atau kesatuan pada } \\
\text { periode waktu yang sama. } \\
\text { (siegel, Shim dalam } \\
\text { Kurdi, 1999:340) }\end{array}$ & $\begin{array}{l}\text { - Net Operating Profit } \\
\text { After Tax (NOPAT) } \\
\text { - Weighted Average } \\
\text { Cost } \\
\text { of Capital (WACC) } \\
\text { - Average Invested } \\
\text { Capital (AIC) }\end{array}$ & $\begin{array}{l}\text { Rupiah } \\
\text { (Rp) }\end{array}$ & Rasio \\
\hline
\end{tabular}

\section{Hasil Penelitian}

Data Hasil penelitian untuk Variabel komersialisasi Biaya Rawat Inap Pasien (X) pada RSUD Kota Tasikmalaya

Komersialisasi biaya rawat inap pasien yang ada pada RSUD Kota Tasikmalaya dapat terlihat antara lain dari adanya berbagai macam jenis tarif bagi pasien.

Agar komersialisasi biaya rawat inap pasien dapat memberikan dampak yang positif bagi semua pihak, maka pihak manajemen rumah sakit harus mampu memberikan pelayanan yang baik terhadap masyarakat yang membutuhkan. Adapun pelayanan yang diberikan oleh rumah sakit berbeda-beda, sehingga menyebabkan adanya berbagai macam tarif yang disesuaikan dengan jenis pelayanan yang diberikan. Tarif pelayanan kesehatan terdiri dari 2 (dua) komponen yaitu jasa pelayanan dan jasa sarana.

Berikut adalah data variabel komersialisasi biaya rawat inap pasien $(\mathrm{X})$ dengan indikator sesuai dengan komponen tarif yang telah dikemukakan diatas, adalah sebagai berikut : 
Tabel 4.1

Data Hasil Penelitian Untuk Variabel Komersialisasi Biaya Rawat Inap Pasien (X)

\begin{tabular}{|c|c|c|c|c|}
\hline Tahun & Jasa Pelayanan & Jasa Sarana & Jumlah & $\begin{array}{c}\text { Perubahan } \\
\%\end{array}$ \\
\hline 1998 & Rp.1.404.794.751 & Rp $\quad 5.547 .447 .889$ & Rp $\quad 6.952 .242 .640$ & - \\
\hline 1999 & $\operatorname{Rp} 1.643 .034 .796$ & $\mathrm{Rp} \quad 6.488 .243 .145$ & Rp 8.131.277.942 & 14,5 \\
\hline 2000 & $\operatorname{Rp} 1.856 .536 .493$ & $\operatorname{Rp} 7.331 .348 .187$ & Rp 9.187 .884 .680 & 11,5 \\
\hline 2001 & $\operatorname{Rp} 2.121 .755 .992$ & $\operatorname{Rp} \quad 8.378 .683 .642$ & $\operatorname{Rp} 10.500 .439 .634$ & 12,5 \\
\hline 2002 & $\operatorname{Rp} 2.357 .506 .658$ & $\operatorname{Rp} 9.309 .648 .491$ & $\operatorname{Rp} 11.667 .155 .149$ & 10 \\
\hline 2003 & $\operatorname{Rp} 2.725 .441 .223$ & $\operatorname{Rp} 10.762 .599 .412$ & $\operatorname{Rp} 13.488 .040 .634$ & 13,5 \\
\hline 2004 & $\operatorname{Rp} 3.114 .789 .969$ & $\operatorname{Rp} 12.300 .113 .613$ & $\operatorname{Rp} 15.414 .903 .582$ & 12,5 \\
\hline 2005 & $\operatorname{Rp} 3.664 .458 .787$ & $\operatorname{Rp} 14.470 .721 .898$ & $\operatorname{Rp} 18.135 .180 .685$ & 15 \\
\hline 2006 & $\operatorname{Rp} 5.570 .379 .769$ & Rp 21.241.919.847 & $\operatorname{Rp} 26.812 .299 .616$ & 32,4 \\
\hline
\end{tabular}

Sumber : RSUD Kota Tasikmalaya (Data primer yang diolah)

\section{Kinerja RSUD Kota Tasikmalaya}

Pengukuran kinerja merupakan salah satu unsur penting dalam sebuah perusahaan atau organisasi untuk mengetahui baikp atau tidaknya kinerja perusahaan atau organisasi tersebut. Hasil pengukuran kinerja ini juga dapat digunakan sebagai sarana manajemen untuk menganalisa dan mendorong efisiensi kerja untuk memudahkan manajemen dalam pengambilan keputusan.

Kinerja RSUD berkenaan dengan Economic Value Added (EVA) secara spesifik dapat dirumuskan :

\section{EVA $=$ NOPAT $-($ WACC $\times$ Average Invested Capital)}

Dalam penelitian ini penulis mengambil laba ekonomi berdasar perolehan pada tahun 1998 sampai tahun 2006.

Adapun hasil perhitungan dari EVA yang dapat dicapai dari tahun 1998-2006 adalah seperti terlihat pada Tabel 4.2 berikut ini :

Tabel 4.2

Data Hasil Penelitian untuk Kimerja RSUD (Y)

\begin{tabular}{|c|c|c|c|}
\hline No & Tahun & $\begin{array}{c}\text { Economic Value Added } \\
\text { (EVA) }\end{array}$ & $\begin{array}{c}\text { Perubahan } \\
\%\end{array}$ \\
\hline 1. & 1998 & Rp. 548.993.014 & - \\
\hline 2. & 1999 & Rp. 642.097.092 & 14,5 \\
\hline 3. & 2001 & Rp. 725.533 .438 & 11,5 \\
\hline 4. & 2001 & Rp. 829.181.073 & 12,5 \\
\hline 5. & 2002 & Rp. 921.312 .302 & 10 \\
\hline 6. & 2003 & Rp. 1.065 .100 .928 & 13,5 \\
\hline 7. & 2004 & Rp. 1.217 .258 .203 & 12,5 \\
\hline 8. & 2005 & Rp. 4.951.309.220 & 75,42 \\
\hline 9. & 2006 & Rp. 7.336.607.962 & 32,51 \\
\hline
\end{tabular}




\section{Pembahasan}

Komersialisasi Biaya Rawat Inap Pasien (X) Pada RSUD Kota Tasikmalaya

Pada tabel 4.1 di atas, maka pencapaian komersialisasi biaya rawat inap pasien pada RSUD Kota Tasikmalaya mengalami peningkatan secara terus menerus. Adapun peningkatan tertinggi terjadi pada tahun 2006 yaitu sebesar 32,4 \% atau sebesar Rp 8.677.1 18.931. Hal ini disebabkan karena pada tahun tersebut menggunakan tarif baru atau adanya kenaikkan tarif dari tahun-tahun sebelumnya.

Selain tahun 2006 kenaikkan tertinggi terjadi pada tahun 2003 yaitu sebesar 13,5 \% atau sebesar $\operatorname{Rp} 1.166 .715 .515$. Hal ini disebabkan karena pada tahun 2003 pendapatan jasa obat-obatan mengalami peningkatan sebesar $R p$ 1.091.066.506, dan pendapatan jasa pelayanan mengalami peningkatan sebesar Rp 367.934.565.

\section{Kinerja RSUD Kota Tasikmalaya (Y) Pada RSUD Kota Tasikmalaya}

Kinerja RSUD berdasarkan tabel 4.2 diatas, diketahui bahwa nilai Economic Value Added (EVA) terbesar sebesar Rp 7.336.607.962 yang diperoleh pada tahun 2006, angka ini menunjukkan bahwa pada tahun 2006 mendapatkan tambahan nilai ekonomis yang positif (EVA) mengindikasikan bahwa kinerja RSUD baik karena mendapatkan tambahan nilai ekonomis. Begitu pula dengan tahun-tahun yang lainnya ternyata setelah dihitung mendapat nilai EVA yang positif yang berarti RSUD mendapatkan tambahan nilai ekonomis dengan performance kinerja yang baik pula.

Nilai Net Operating Profit After Tax (NOPAT) di RSUD memiliki jumlah yang berbeda pada tiap tahunnya. Hal tersebut disebabkan antara lain karena jumlah pendapatan yang diterima berbeda pada tiap tahunnya. Pendapatan Operasi yang bernilai negatif dapat ditutup dengan adanya penerimaan pembiayaan dari Pemerintah Daerah. Karena RSUD Kota Tasikmalaya merupakan RSU milik pemerintah, maka pendapatan bunga, pendapatan investasi lainnya, pajak penghasilan, serta pembebanan pajak terhadap biaya bunga di RSUD Kota Tasikmalaya bernilai nol.

Begitu pula dengan nilai Weighted Average Cost of Capital (WACC), yang memiliki jumlah hutang jangka panjang dan modal sendiri berbeda pada tiap tahunnya. Seperti yang telah dikemukakan diatas, karena RSUD merupakan RSU milik pemerintah, maka saham preferen serta modal investasi rata-rata (Average Invested Capital) bernilai nol.

Perbedaan jumlah EVA pada tiap tahun, dimana yang terendah berjumlah $R p$ 548.993.014. Tapi hal ini tetap mengindikasikan EVA yang positif sehingga ada peningkatan kinerja yang baik pada tiap tahunnya. Perbedaan ini dikarenakan oleh adanya pendapatan yang diperoleh dan penerimaan bantuan yang diperoleh pada tiap tahunnya oleh RSUD tersebut.

Tetapi pada umumnya kinerja RSUD selama 9 tahun menunjukan hasil yang positif, ini ditandai dengan nilai EVA dari tahun 1998 sampai dengan tahun 2006 ini bernilai positif.

\section{Pengaruh Komersialisasi Biaya Rawat Inap Pasien Terhadap Kinerja Rumah Sakit Pada RSUD Kota Tasikmalaya}

Berdasarkan uraian-uraian diatas, menggambarkan secara umum kondisi finansial RSUD yang menjadi subjek penelitian. Dimana pada bagian sebelumnya Jurnal Akuntansi Riset, Prodi Akuntansi UPI, Vol. 1, No. 2 
penulis telah mengajukan hipotesis bahwa "terdapat pengaruh yang signifikan dari komersialisasi biaya rawat inap pasien terhadap kinerja rumah sakit", dan hipotesis tersebut didasarkan pada kerangka pemikiran sebagaimana dikemukakan dalam bab II skripsi ini.

Komersialisasi Biaya Rawat Inap pasien berdasarkan tabel 4.1 diatas, terlihat bahwa komersialisasi biaya rawat inap pasien yang ada di RSÜD Kota Tasikmalaya dari tahun 1998 - 2006 memiliki perbedaan yang disebabkan oleh biaya jasa pelayanan dan jasa sarana yang berbeda-beda yang diterima oleh RSUD pada tiap tahunnya. Dengan terpenuhinya biaya jasa pelayanan dan biaya jasa sarana dengan baik maka akan menunjukkan suatu kinerja rumah sakit yang baik pula. Dimana kinerja rumah sakit adalah hasil kerja baik secara kualitas atau kuantitas yang ditunjukkan oleh seorang pegawai dalam melaksanakan tugasnya sesuai dengan tanggungjawab yang diberikan kepadanya.

Ukuran kinerja yang dipakai adalah dengan menghitung tambahan laba ekonomis bagi rumah sakit. Jika dalam satu periode rumah sakit mendapatkan tambahan laba ekonomis, maka dapat dikatakan bahwa kinerja rumah sakit meningkat.

\section{Pengujian Hipotesis}

a. Persamaan Regresi

$Y=-25,867+2,016 X$

Persamaan regresi tersebut menyatakan bahwa variabel $\mathrm{X}$ memberikan pengaruh pada variabel $\mathrm{Y}$ (kinerja rumah sakit). Variabel $\mathrm{X}$ memberikan pengaruh sebesar 0,928 yang berarti bahwa pengaruh dari komersialisasi biaya rawat inap pasien terhadap kinerja rumah sakit sangat kuat. Jika tidak ada variabel X $(=0)$ maka rumah sakit tidak akan mengalami kemajuan dalam arti rumah sakit tersebut kinerjanya buruk, karena konstanta menunjukkan angka negatif yaitu $\mathbf{- 2 5 , 8 6 7}$.

b. Koefisien Korelasi

Besar hubungan antara variabel komersialisasi biaya rawat inap pasien dengan kinerja rumah sakit sebesar 0,928 hal ini menunjukkan hubungan yang sangat erat dan mempunyai hubungan yang positif sebesar 0,928 . Adanya korelasi positif antara variabel independen dan variabel dependen, ini berarti kenaikan yang terjadi pada komersialisasi (variabel $\mathrm{X}$ ) akan senantiasa diikuti dengan kenaikan kinerja rumah sakit (variabel Y). Demikian pula sebaliknya.

Tingkat signifikasi koefisien korelasi dari output (diukur dari probabilitas) menghasilkan angka 0,000 . Oleh karena probabilitasnya dibawah 0,05 , maka korelasi antara komersialisasi biaya rawat inap pasien dengan kinerja rumah sakit adalah nyata.

Terlihat bahwa pada kolom sig/significance adalah 0,000 atau probabilitasnya dibawah 0,05 , maka Ho ditolak atau koefisian regresi signifikan, dengan kata lain komersialisasi biaya rawat inap pasien benar-benar berpengaruh secara signifikan terhadap kinerja rumah sakit.

c. Koefisien Determinasi

Untuk mengetahui berapa besarnya pengaruh komersialisasi biaya rawat inap pasien terhadap kinerja rumah sakit, menggunakan koefisien determinasi $\left(\right.$ square/ $\left.\mathrm{rd}=(\mathrm{r})^{2}\right)$ 
dan didapat angka $\mathrm{R}$ square atau koefisien determinasi sebesar 0,862 yang dalam hal ini berarti kinerja rumah sakit selama 9 tahun dipengaruhi oleh komersialisasi biaya rawat inap pasien sebesar $86,2 \%$. Sedangkan sisanya disebabkan oleh faktor lain.

d. Pengujian Hipotesis

Didapat bahwa thitung adalah sebesar 6.607 sedangkan $t_{\text {tabel }}$ dengan tingkat signifikansi $\alpha=0,05$ dan df adalah $9-2=7$ didapat angka 2,365 . Ternyata $t_{\text {hitung }}>$ dari $t_{\text {tabel }}(6,607>2,365)$. Hal ini berarti koefisien korelasi signifikan. Dengan demikian hipotesis Ho ditolak dan hipotesis alternatif Ha diterima. Diterimanya hipotesis alternatif menunjukkan bahwa pada tingkat keyakinan 95\% komersialisasi biaya rawat inap pasien berpengaruh secara signifikan terhadap kinerja rumah sakit.

\section{Simpulan}

Berdasarkan hasil penelitian dan pembahasan mengenai pengaruh komersialisasi biaya rawat inap pasien terhadap kinerja rumah sakit pada Rumah Sakit Umum Daerah Kota Tasikmalaya, maka penulis mengambil kesimpulan sebagai berikut :

1. Komersialisasi biaya rawat inap pasien yang ada pada Rumah Sakit Umum Daerah Kota Tasikmalaya pada umumnya memiliki dampak yang positif bagi semua pihak. Bagi rumah sakit termasuk manajemen, dokter, tenaga medis dan tenaga non medis lainnya akan lebih leluasa dalam memberikan pelayanan yang optimal antara lain dengan penggunaan teknologi yang lebih canggih dalam memberikan pelayanan kesehatan kepada masyarakat. Sedangkan bagi masyarakat pemakai jasa rumah sakit akan mendapat kenyamanan dan kemudahan dalam pelayanan kesehatan. Biaya jasa pelayanan maupun biaya jasa sarana yang ditetapkan pun pada umumnya telah sesuai dengan peraturan perundang-undangan yang berlaku, serta pihak manajemen telah memberikan pelayanan yang baik sesuai dengan kebutuhan serta kondisi perekonomian pasien.

2. Kinerja rumah sakit yang ditunjukkan selama 9 tahun yaitu dari tahun 1998 sampai dengan tahun 2006 cukup baik. Hal ini bisa dilihat dengan perolehan EVA yang positif. Economic Value Added (EVA) yang dihasilkan oleh rumah sakit selama 9 tahun mempunyai jumlah yang berbeda-beda. Hal ini disebabkan adanya perbedaan pendapatan dan penerimaan bantuan yang diterima oleh RSUD pada tiap tahunnya.

3. Berdasarkan hasil analisis dengan menggunakan SPSS versi 15 , diperoleh hasil bahwa $t_{\text {hitung }}>t_{\text {tabel }}$ yaitu sebesar 6,607 $>2,365$. Dengan demikian dapat dinyatakan bahwa komersialisasi biaya rawat inap pasien berpengaruh signifikan terhadap kinerja RSUD Kota Tasikmalaya.

\section{Saran}

Berdasarkan kesimpulan yang dikemukakan di atas, penulis mencoba memberikan saran-saran diantaranya sebagai berikut :

1. Bagi Rumah sakit 
Kinerja rumah sakit harus ditingkatkan dengan melihat faktor pemicu dari meningkatnya kinerja personel dan manajer rumah sakit. Penilaian yang dipakai adalah dengan EVA maka rumah sakit perlu meningkatkan jumlah EVA dengan melihat apakah rumah sakit lebih baik hanya dibiayai modal sendiri . (pemerintah) atau pinjaman (pihak lain).

2. Bagi peneliti selanjutnya

Penelitian yang dilakukan selanjutnya sebaiknya dilakukan pada waktu yang lebih lama. Selain itu, aspek yang dijadikan ukuran kinerja sebaiknya tidak hanya aspek keuangan tetapi meliputi aspek non keuangan.

\section{Daftar Pustaka}

Azwar, Azrul, 1996, Pengantar Administrasi Kesehatan, Binarupa Aksara, Jakarta.

Echols, John M. \& Hassan Shadily,1990, Kamus Inggris-Indonesia, PT. Gramedia

Pustaka Utama, Jakarta.

Mohamad, Kartono, 1995, Rumah Sakit dalam Medan Magnetik Komersialisasi, dalam

K. Bertens, Rumah Sakit: Antara Komersialisasi dan Etika, PT. Gramedia

Widiasarana Indonesia, Jakarta.

Mohammad Nazir. 2003. Metode Penelitian. Jakarta : Ghalia Indonesia.

Mudrajat Kuncoro . 2001. Metode Kuantitatif. Yogyakarta : UPP AMP YKPN

Mulyadi. 2001. Akuntansi Manajemen konsep Manfaat \& Rekayasa .Edisi 3. Jakarta :

Salemba Empat.

Robert N. Anthony dan Vijay Govindarajan, Alih Bahasa : F.X. Kurniawan Tjakrawala. 2003. Sistem Pengendalian Manajemen, Buku 2. Jakarta : Salemba Empat.

Siegel \& Shim. Kamus Istilah Akuntansi, Alih Bahasa : Moh. Kurdi. 1999. Jakarta: PT. Elex Media Komputindo.

Soekanto, Soerjono \& Herkutanto, 1987, Pengantar Hukum Kesehatan, Remadja Karya, Bandung.

Sugiyono. 2003. Metode Penelitian Administrasi. Edisi Revisi. Bandung : Alfabeta

Supriyono. 1990. Akuntansi Biaya, Pengumpulan Biaya dan Penentuan Harga Pokok

Thiroux, Jacques P., 1980, Ethics, Theory and Practice, Glencoe Publishing Company, Inc. Encico, Califomia.

Tim Penyusun Kamus Besar Bahasa Indonesia, 1988, Kamus Besar Bahasa Indonesia, Balai Pustaka, Jakarta.

Trisnantoro, Laksono, 17 Pebruari 2000, "Perubahan Rumah Sakit Menjadi Lembaga Usaha yang Berfungsi Sosial", Makalah Seminar Masa Depan Rumah Sakit Keagamaan, Diselenggarakan Oleh Pusat Manajemen Pelayanan Kesehatan Fakultas Kedokteran UGM, Yogyakarta.

Warsono. 2003. Manajemen Keuangan Perusahaan, Edisi 3, Buku 1. Malang : Bayumedia Publishing.

Wijaya, Hans, P., 19 Juni 2000, Aliansi Strategis Rumah Sakit-rumah sakit Keagamaan, Makalah Seminar Masa Depan Rumah Sakit Keagamaan, 
Diselenggarakan Oleh Pusat Manajemen Pelayanan Kesehatan Fakultas Kedokteran UGM, Yogyakarta

Young, S. David dan Stephen F. O’Byrne. 2001. EVA dan Manajemen Berdasarkan Nilai. Jakarta : Salemba Empat.

Yuni Lestari, Ahdiana. 15 Juni 2002. Aspek Hukum Komersialisasi Rumah Sakit Swasta Dalam Kaitannya Dengan Pelayanan Kesehatan Yang Berfungsi Sosial Di Kota Yogyakarta. Fakultas Hukum Universitas Muhammadiyah. Yogyakarta $\underline{2007,20: 45}$ from : http://www.drn.go.id/download/p.doc. Dikutip tanggal $20 \mathrm{Mei}$

Peraturan Perundang-undangan

Peraturan Daerah Kota Tasikmalaya Nomor 4 Tahun 2006 tentang Ketentuan Khusus dan Retribusi Pelayanan Kesehatan Pada RSUD Kelas B Non Pendidikan Kota Tasikmalaya

Peraturan Departemen Kesehatan RI Nomor 154/Men. Kes/SK/IV/78 tentang Klasifikasi Rumah Umum.

Peraturan Menteri Kesehatan Republik Indonesia Nomor 159b Tahun 1988 tentang Rumah Sakit.

Peraturan Pemerintah Nomor 23 Tahun 2005 tentang Badan Layanan Umum.

Peraturan Pemerintah Republik Indonesia Nomor 66 Tahun 2001 Pasal 8 tentang Retribusi Daerah

SK Menteri Kesehatan Republik Indonesia nomor 282/Men. Kes./II/1993 tentang Pola Tarif Rumah Sakit

Undang-undang Nomor 23 Tahun 1992 tentang Kesehatan. 